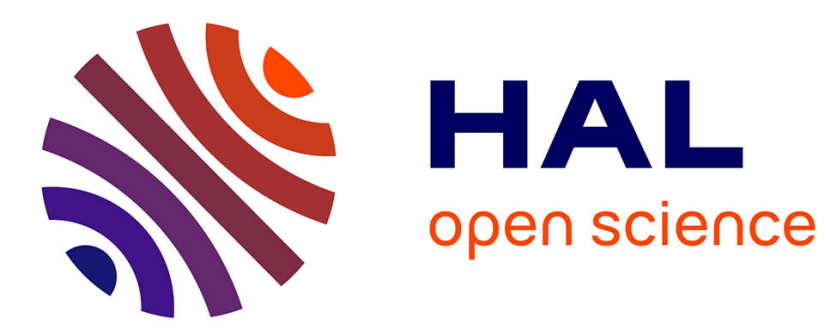

\title{
The ECORS system: A mobility decision-making tool based on Earth observation data
}

Audrey Hohmann, Gilles Grandjean

\section{To cite this version:}

Audrey Hohmann, Gilles Grandjean. The ECORS system: A mobility decision-making tool based on Earth observation data. International Cartographic Conference 2011, Jul 2011, Paris, France. hal-00589833

\section{HAL Id: hal-00589833 https://hal-brgm.archives-ouvertes.fr/hal-00589833}

Submitted on 2 May 2011

HAL is a multi-disciplinary open access archive for the deposit and dissemination of scientific research documents, whether they are published or not. The documents may come from teaching and research institutions in France or abroad, or from public or private research centers.
L'archive ouverte pluridisciplinaire HAL, est destinée au dépôt et à la diffusion de documents scientifiques de niveau recherche, publiés ou non, émanant des établissements d'enseignement et de recherche français ou étrangers, des laboratoires publics ou privés. 


\title{
THE ECORS SYSTEM: A MOBILITY DECISION-MAKING TOOL BASED ON EARTH OBSERVATION DATA
}

\author{
HOHMANN A., GRANDJEAN G. \\ BRGM, ORLEANS, FRANCE
}

\section{BACKGROUND AND OBJECTIVES}

In operational contexts where forces have to be deployed on unknown areas, the capacity of terrestrial vehicles to move both on and off road can be determinant. Modeling such capacity remotely, without any in situ observations, constitutes the objective of the ECORS project. Scientists and professionals of the geotechnical, remote sensing and decision-making system domains have joined their forces to develop a prototype which could help military forces in decisions related to mobility. This prototype intends to characterize operations theatres from Earth observation data, and to produce geophysical and environmental maps as well as decision aid documents. The system architecture allows a fast and an automatic analysis that can be easily implemented in cartographic representations.

\section{APPROACH \& METHODS}

The parameters affecting the mobility of an ATV (All Terrain Vehicle) in soft ground interact in complex ways and depend on vehicle performance, the pilot's actions, the meteorology, the geologic parameters.... The purpose of ECORS is to develop a decision-making tool based on such parameters to estimate the vehicle performance. For different kinds of vehicles, decision maps are oriented from a strategic, operative and tactical point of view. The main data sources authorized are those coming from remote sensors, including remotesensing data, existing databases, i.e., Topobase Defense, HWSD, NCAR DB, etc or opensource data. The elementary layers produced from these data and used in the calculations are: the tracks and roads, the terrain slope, the landuse, the soil nature, moisture and roughness. These layers are then analyzed in a GIS and supplemented if necessary on a scale of work that is based on different levels of operation. All these parameters were used to predict the vehicle performances, including speed, by comparing them to a database compiling standard cases of mobility. The resulting map shows the places where the vehicle can go without problems (green), with a relatively slow velocity (orange) and where it can't go (red) with a resolution of $30 \mathrm{~m}$ thanks to the DTED2 DEM. Calculations are performed using a Ground Vehicle Interaction (GVI) processing module, both off road but also on road, using a VMAP2i model, enriched by additional fields necessary to the ECORS estimators such as the maximum slope and sinuosity, presence of water or ice on the coating, presence of fords, bridges or tunnels.

\section{RESULTS}

In the present work, the ECORS system was tested on different test sites in France and Morocco. From a general point of view, the system delivers results in good agreement with observations (Land use classes, soil type, moisture, etc) measured on the field. A systematic study has been realized over different areas featured by different geographical contexts. The rate of success ranges between 97, 56 and 78\%, depending on the considered area. Basically, most of errors were generated by two kinds of factors:

1-Some little escarpments $(5-10 \mathrm{~m})$ were underestimated because of a lack of resolution of the DEM $(30 \mathrm{~m})$ that smoothed these topographic effects. In consequence, such barriers were wrongly considered as passable for the different vehicles; 
2-Land use classification suffered also of some attribution errors between forest and bush. These confusions lead to pronounce NOGO on places considered as forest that were bush in reality.

3-Vehicle speed was also altered by some difficulties for estimating realistic soil moisture. Indeed, this quantity being estimated from climatic considerations is generally slightly different from what is observed in reality, and thus can produce variations in the final diagnosis.

Despite such limitations, DAMs where successfully validated; they offer a valuable information for planning operational missions over badly known areas.

\section{CONCLUSION AND FUTURE PLANS}

In the present work, a decision-making system was designed, developed and tested in order to estimate vehicles mobility in both cross-country and roads modes. The ECORS system is based on processing, interpretation and data-fusion processes from remote sensing data, existing databases, including e-sources. Computing algorithms include slope computation, moisture index, land use and soil classification, road description, etc. Results are compiled in decision-making maps where two levels of information are available: NOGO and velocity maps, depending on data exhaustiveness. Validation processes have been carried out for verifying the coherence of these maps. Results show a good agreement between prediction and field observations, except for terrain with high complexity or non-exhaustive data. As perspectives, new field validation will be carried out in the next few months, particularly for testing the system in zones representative of operational areas.

\section{ACKNOWLEDGEMENTS}

The project was funded by DGA and has support from operational military French Forces. The ECORS project Team is composed by the following French organisms and industrials Brgm, Onera, Geo212, Sertit and Car\&D.

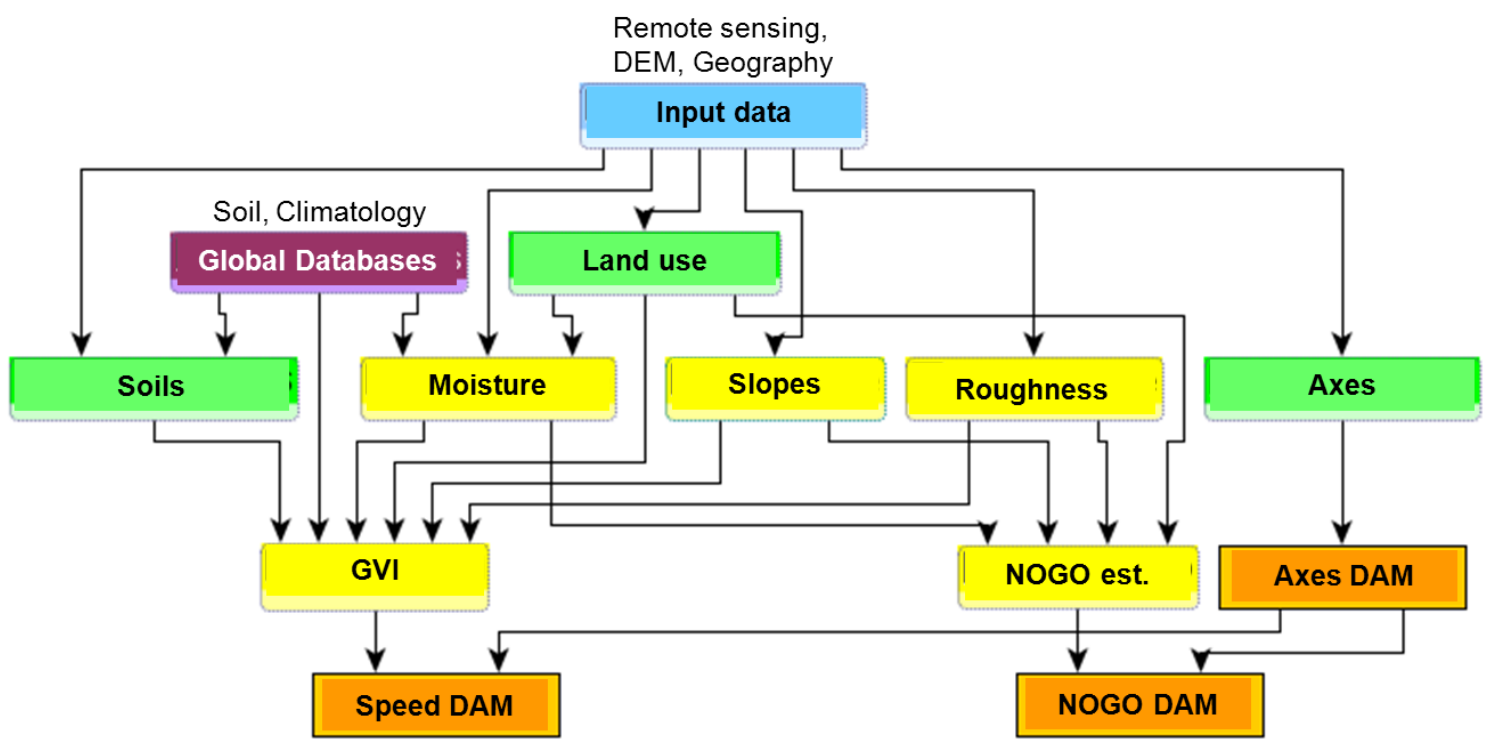

Figure.1: general workflow of the ECORS system; terrain parameters are indicated in green, calculations in yellow and Decision Aid Maps (DAMs) in orange; GVI: Ground Vehicle Interaction processing. 


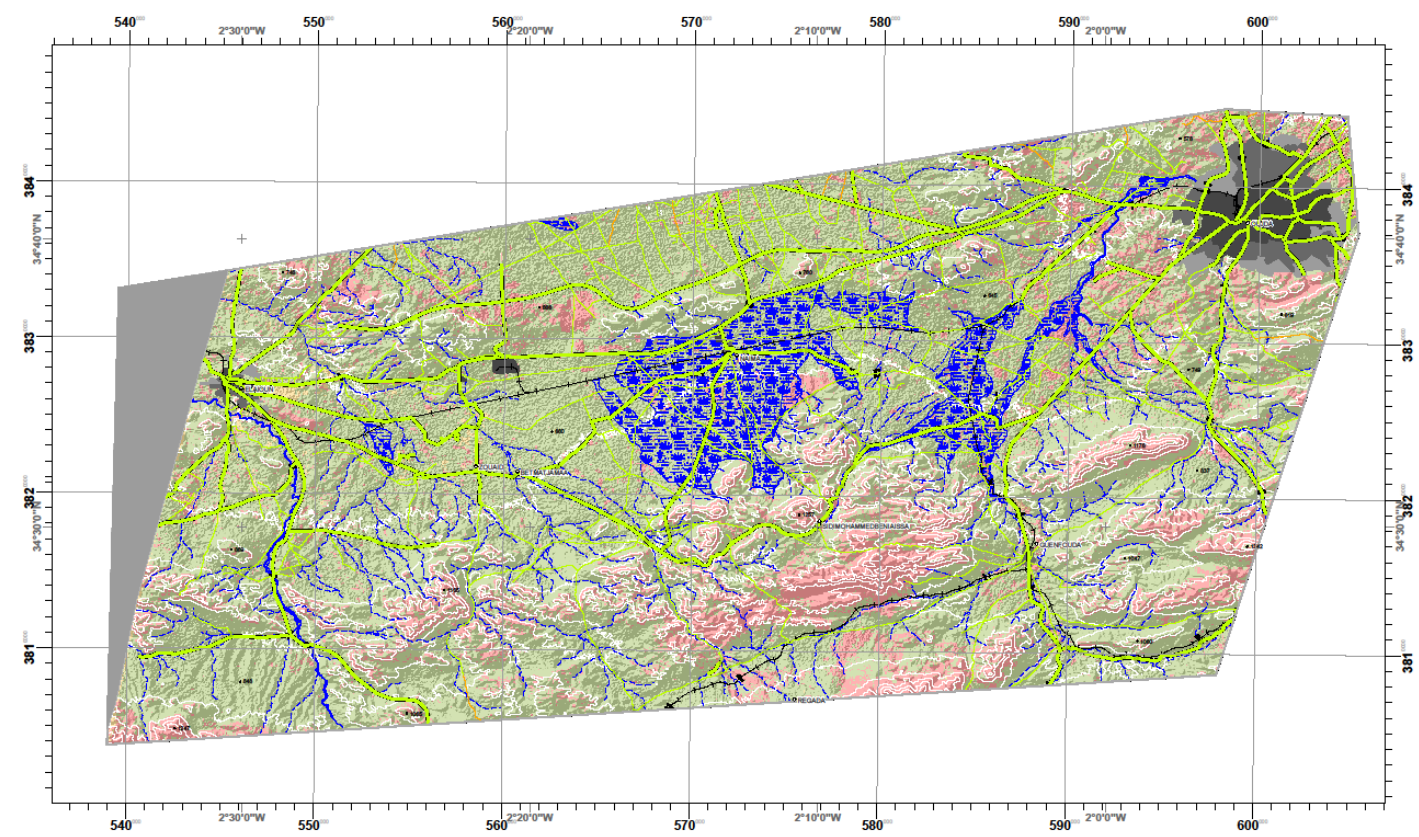

Figure.2: DAM for a 4x4 vehicle computed over an area located in the north-eastern part of Morocco; green, yellow, red colors refer to go, slow-go and no-go velocity classes, on and off-road respectively; blue and grey parts represent the floodplains and urban zones respectively. 